\title{
Influence of Fiscal Federalism as Budget Efficacy on Household Income in Kenya
}

\author{
Cyrus M. Munyua ${ }^{1}$ Stephen Muchina ${ }^{2} \quad$ Beatrice Ombaka $^{3}$ \\ School of Business, Karatina University, PO Box 1957-10300 Karatina, Kenya
}

\begin{abstract}
The Theory of federalism suggests that a fiscal decentralization negatively affects the size of a government budget. Indeed, the size of the national budget in Kenya has been ballooning ever since the inception of fiscal decentralization. What is of concern to this study is its efficacy and ultimate effect on household income. The importance of the hypothesis of fiscal federalism was tested by adopting the Survey and Evaluation Program (NASSEP V) frame that the Kenya Bureau of Statistics currently operates to conduct household-based in Kenya. The study employed an inductive ex post facto cross sectional quantitative survey design. Secondary panel data was collected from County Treasuries while Primary data was collected through household surveys and Fiscal and Monetary Departments of county assemblies. The study established a significant association between budget efficacy and household income as indicated by a beta coefficient of 0.9021 and a p' value of 0.000 . The beta coefficient has positive sign, which indicates that there is a direct relationship between budget efficacy and household income. An increase in budget efficacy is expected to have a positive influence on household income. The findings of this study are expected to empower citizens through access of information on the real meaning and effects of fiscal asymmetric decentralization while policy makers will know the strength of the correlation between fiscal asymmetry and household effect in order to match monetary policy with the needs of lower government levels for implementation of the country's financial framework.
\end{abstract}

Keywords: Fiscal Federalism, Budget Efficacy, Household Effects.

DOI: $10.7176 / \mathrm{EJBM} / 11-15-10$

Publication date:May $31^{\text {st }} 2019$

\subsection{Introduction}

The concept of federalism was originally proposed by Brennan and Buchanan (1980). The concept states that intrusion of government into economy can be restricted if responsibilities of government with respect to taxes and expenditures are decentralized. Fiscal decentralization has been defined as the process of shifting the responsibilities of revenue collection and expenditure execution from the central to sub-national authorities. The level of fiscal Decentralization is however lower in developing than in advanced economies. It is therefore imperative to analyze whether fiscal decentralization should be expanded in less developed economies considering that the average share of expenditure managed at the sub-national level is about $25 \%$ compared to in developing economies, compared $40 \%$ in advanced economies. The average shares on the revenue side are $23 \%$ and $37 \%$ respectively.

Hayek (1945), Tiebout (1956) and Musgrave (1969), states that fiscal decentralization can allow for a better prioritization of the provision of public goods and thus, reduces wastes by increasing information asymmetry among local authorities on the needs of the local population.

Baskaran (2010) also defines Fiscal decentralization as the process of shifting the responsibilities of revenue collection and expenditure execution from the National to sub-national authorities. Unfortunately the level of fiscal Decentralization is however lower in developing economies than in advanced economies. It is therefore imperative to analyze whether fiscal decentralization should be expanded in less developed economies considering that the average share of expenditure managed at the sub-national level is about $25 \%$ compared to in developing economies, compared $40 \%$ in advanced economies. The average shares on the revenue side are $23 \%$ and $37 \%$ respectively.

About 75 countries all over the World have attempted to decentralize responsibilities to lower tiers of government in the last quarter century in one way or another. It is also estimated that over $80 \%$ of the World in the late 1990's, were experimenting various forms of devolution. Many developed countries have increased their degree of fiscal decentralization, starting with Europe which has been on top of the list, followed by Austria, Germany, Switzerland, Belgium, Italy and Spain just to mention a few. Various public services highlight fiscal decentralization in the United States by transfers of services to the regional governments, for example, welfare, Medicaid, legal services, housing and job training (Oates, 1999).

Some of the African countries that have also decentralized their provision of goods and services from the national level to devolved units include Botswana, Burkina Faso, Ethiopia, Ghana, Mali, Mozambique, Nigeria, South Africa, Tanzania, Uganda and Kenya (Dickovick\&Riedl, 2010).

Households are the owners of the factors of production and are therefore likely to be affected by Fiscal policy shocks. The welfare of individuals can therefore be affected by fiscal decentralization which transfers the financial 
responsibilities from the national government to the county government. This agrees with the key economic rationales for decentralization advanced by Musgrave (1959) and Oates (1972), who argue that decentralization may improve governance in public service provision by improving the efficiency of resource allocation. In this vein, many developed countries have increased their degree of fiscal decentralization. Europe is on top of the already federalized Austria, Germany, and Switzerland, Belgium, Italy, and Spain have recently introduced widespread reforms in order to enhance regional autonomy (Ezcurra and Rodriguez-Pose 2010).

Different reasons are advanced as a cause of decentralization but above all, it is argued that federalism is a panacea to all problems bedeviling developing countries starting with the continuing household income inequalities in most African countries. The proponents of this argument are informed by Oates (1956) model on fiscal federalism which argue that locals have the know-how on the needs of the local community. In this vein the Constitution of Kenya 2010 and the Public Management Act 2012 requires that local community be involved in Budgetary Public Participation process. The National Treasury takes a leading role as well as an oversight role to ensure that public participation forum takes place in all the 47 county governments in Kenya. It is believed the outcome will be a budget efficacy and an improved household income as the budget takes cognizance of the disposable income.

Budgeting has been defined as the basis of the management control process in organizations (Hansen et al, 2003) and also traditionally described as a common accounting tool that organizations use for implementing strategies (Ostergren \& Stensaker, 2011). The basic objective of budgeting is to give those targets and plans financial values, hence making an early progress in an easily measurable manner to transform the strategic ideas into understandable operative actions (Hanninen, (2013).

Olomola, (2009), postulate that a budget is not only used for mobilization and resource allocation but also the budget does not only function as a mechanism for resource mobilization and allocation, it also serves as a tool for economic management. This emphasized in the Government Integrated Financial Management Information System (Odago, M. O., \& Mwajuma, A. A. 2013).

It will be very difficult for any government to realize its vision without having a comprehensive budget because a government's accounting system is cash based as opposed to the accrual basis of accounting. The budget document lays down the direction for the entire economy and determines who gets what and when, as well as a basis for the provision of funds to implement new initiatives/policies through legal, rational and acceptable means (Bengali, 2004).

A government budget is one of the accounting tools used to plan the government revenues for a specific future fiscal period. It is also considered as a general law which gets approved by the legislative authority represented by the parliament. This means that the government general budget depends mainly on estimation and approval. The promulgation of the Constitution of Kenya 2010 completely changed the way public budgets were previously done in Kenya. It introduced a new legal framework and institutions to ensure transparency, accountability and public participation in management of public finances by providing a way which involve ordinary Kenyans in the budget making process, a complete turnaround from the previous regime where the budget making process was the work of a select few (Adili 2015)

Comparison of the trends of tax revenue with those of expenditure, both as a percent of GDP over the last decade in Kenya reveals that expenditure has persistently been growing at a faster rate than tax revenue growth, for example. For 2015/16, out of an estimated budget of Ksh 2,247 billion and projected revenue of 1,358 billion, the expected fiscal deficit is Ksh 889 billion up from 740 billion in 2014/15 revised budget. A paucity of empirical literature attributes this escalation of budget deficit to devolution related expenditure, for example Pierre and Peters (2011) indicates that an effective budget must first of all be adopted by a duly constituted authority, and it must be adhered to. The government must also avail the information on budgets to the public, who must have been involved in its preparation and despite the fact that revenue is always limited; the available resources must be matched with the expenditure (Pierre and Peters 2011).

Lienert \& Sarraf, (2001) also assert that lack of basic ingredients of sound budgeting in most African countries, which includes Kenya, has justified the description of their budgetary performances as disappointing, and underscores the need for reforms in public financial management in general and budget management in particular. In Nigeria for example, there was a lot of wasteful spending during a similar period of the stage of devolution like Kenya is now (Ben-Caleb \& Agbude, 2013).

Abdullahi et al, (2012), posit that a national budget need to be well designed for it to be effective and efficiency in its implementation and to monitor the performance of government staff who are the managers of governments units and departments. Recent reforms in Kenya have seen budgeting move away from the previous days during the unitary system of governance where it was the preserve of the executive.

Kazeem O. F, Hakeem O. F, and Reuben O. O, (2014) posit that budgeting is a useful tool that can guide Devolved governments to evaluate whether governments policy and objectives are actualized especially poverty eradication which directly improves household effects which was the focal point of this study. ustapha, Rashid and Nasir (2011) also assert that there is a close relationship between expenditure and household income which is in 
continuum with this study focus. Further.

Previously in Kenya, budgeting, policy and planning have not been conducted in an entirely integrated and comprehensive manner which has resulted into inconsistencies and incoherencies in Kenya's development platforms. The MTEF model has now been adapted for use, which is designed to instill discipline in managing and planning national resources by establishing an explicit link between the policy framework and the budgetary process. It seeks to bring a better integration of policy reforms, budgeting and expenditure management and attempts to link sector objectives to national priorities and thereby achieve greater result from existing level of resources, otherwise the debate on the effect of budget deficit on private consumption has stimulated a burgeoning literature in macroeconomics (Niesner, J., Jecha, D., \& Stehlík, P. 2013).

\subsection{Significance of the study}

This study aims at analyzing the Impact of budget efficacy under a devolved system of governance on the household effects in Kenya. The study adopts a comparative manner for the last five years with a view to preempt any unforeseen negative impacts on the household effects through ignorance of the advantages of devolution or non-control of its weaknesses that there may be.

This study will be beneficial to both citizens and policy makers because citizens in spirit of the need to know principal need to be empowered through access of information on the real meaning and effects of budget efficacy under a devolved system of governance based on the fact that decentralization is a continuum and therefore a process which need to be appreciated by the citizens of a country experiencing this system of governance for the first time. The political class will also benefit from the findings of this study as the peoples representatives endowed with legislative obligation because they will be able to make an analysis of the existing budgetary policy and therefore find out whether there is a tradeoff between the two systems of governance i.e. central and decentralized system and therefore come up with policy recommendations on the way forward based on the researcher's findings.

\subsection{Methodology}

The study adopted a positivist research philosophy in determining the research strategy and method of this strategy. The target population for this study was composed of all the forty-seven county governments in Kenya because each county is unique to its circumstances and the general populace. It contains a total of 5,360 clusters split into four equal sub-samples. These clusters are drawn using a stratified probability proportional to size sampling methodology from 96,251 enumeration areas (EAs) used by the Bureau in the 2009 Kenya Population and Housing Census (NASSEP V) frame that the Kenya Bureau of Statistics currently operates to conduct household-based surveys An inductive ex post facto cross sectional quantitative survey design approach was utilized. Secondary panel data and Primary data for the period 2015-2018 was collected through household surveys.

\subsection{Result and Discussion}

The data used for this study were presented, analyzed and discussed. The section also captures the testing of the only hypothesis of this study

\section{Household Income Characteristics}

Table 1 presents results on association between budget efficacy and household income. The findings indicated that budget efficacy and household income have a strong positive and significant association. This was supported by a correlation value of $0.6163^{*}$. The association between the two variables was significant at $5 \%$ level of significance. The results implied that an increase in budget efficacy would increase household income.

\section{Regression Analysis}

Table 2 present the regression results on the relationship between budget efficacy and household income.

The results indicated that there was a positive and significant relationship between budget efficacy and household income. This was indicated by a coefficient value of 0.9021 and a $p$ value of 0.000 . The results implied that for every one unit change in budget efficacy, household income would change by 0.9021 units holding all factors constant. The coefficient value had a positive sign, which indicated that there was a direct relationship between budget efficacy and household income. An increase in budget efficacy is expected to have a positive influence on household income.

Further, the F value of 85.14 indicated that the model was a good estimate. The p value of 0.000 supported the significance of the model at $5 \%$ significance level. The results implied that budget efficacy is a good predictor of household income. In addition, the $\mathrm{R}^{2}$ value of 0.379 indicated that budget efficacy explained $37.9 \%$ of the total variations in household income. The remaining $62.1 \%$ was explained by other factors that were not included in this study.

The Skewness/Kurtosis test indicated that the data was not normally distributed since the probability value was less than 0.05 . However, normality was assumed since the number of observations was many.Breusch-Pagan test reported a $\mathrm{p}$ value of 0.6182 , which was greater than 0.05 and hence the data was homoscedastic. Further, Wooldridge test reported a $\mathrm{p}$ value of 0.6758 , which was greater than 0.05 and therefore, there was no 
autocorrelation.

Table 2: Regression Model: Budget Efficacy

\begin{tabular}{lcccc} 
& Coef. & Std. Err. & T & P $>|\mathbf{t}|$ \\
\hline Household Income & 1.000 & & 9.23 & 0.000 \\
Budget Efficacy & $0.6163^{*}$ & & & \\
R squared & 0.3798 & & & \\
Adj. R squared & 0.3754 & & & \\
F $(1,139)$ & 85.14 & & \\
Prob. $>$ F & .00 & & \\
Skewness/Kurtosis test & Chi2 $=55.90$, Prob $>$ chi2 $=0.000$ & \\
Breusch-Pagan test & Chi2 $=0.25$, Prob $>$ chi2 $=0.6182$ & & \\
Wooldridge test & $\mathrm{F}(1,46)=0.177$, Prob $>\mathrm{F}=0.6758$ & & \\
\hline
\end{tabular}

Specific model:

$\mathrm{Y}=\alpha+\beta \mathrm{X}$

Household Income = 0.3624+0.9021 Budget Efficacy

The Skewness/Kurtosis test indicates that the data was not normally distributed since the probability value is less than 0.05 . However, normality was assumed since the number of observations was large. Breusch-Pagan test reported a $p$ value of 0.6182 , which is greater than 0.05 and hence the data was homoscedastic. Further, Wooldridge test reported a $\mathrm{p}$ value of 0.6758 , which is greater than 0.05 and therefore, there was no autocorrelation. The resultant model when household effect is measured in terms of household income is:

Household Income $=0.3624+0.9021 \mathrm{BE}$

The hypothesis was tested by using the OLS regression. The acceptance/rejection criteria was that, if the $\mathrm{p}$ value is less than the conventional $\mathrm{p}$ value at 5\% significance level, the null hypothesis is rejected, otherwise the null hypothesis is not rejected. The null hypothesis was that there is no significant association between County Budget Efficacy and Household Effects.

Based on results in Table 2, the null hypothesis was rejected since the p value of 0.000 , was less than the conventional $\mathrm{p}$ value of 0.05 . Therefore, the null hypothesis was rejected and this implied that there was a significant association between County budget efficacy and household effects.

\subsection{Conclusions and Recommendations}

The study concludes that there is a significant association between Budget Efficacy as indicated in hypothesis $\mathrm{H}_{01}$. and also concludes that budgeting is a useful tool that can guide Devolved governments to evaluate whether governments policy and objectives are actualized especially poverty eradication which directly improves household effects in Kenya. This is also in continuum with Oate (1951) traditional Theory of Fiscal decentralization which emphasizes that locals are able to make better choices and therefore improves efficiency in the provision of Public Service.

The study recommends that budget efficacy is the ideal tool for reducing income inequalities and therefore improving household effects in Kenya. The Study recommends further studies on the influence of budgeting on household effects. The findings of this study will go a long way to inform the national Treasury on the best practice in the ongoing implementation of fiscal decentralization and assist future policy formulation. It will also be a good point of reference in the 47 County governments' budget formulation strategies in the provision of the Public Service and optimum utilization of the available resources for the benefits of household effects in Kenya. This study finds that there is need for a new budget culture in the public sector. Feedback is also an essential ingredient of the budgetary process, if budget efficacy is to be achieved.

\section{References}

Barasa, R., 2014. Influence of monitoring and evaluation tools on project completion in Kenya: a case of constituency development fund projects in Kakamega County, Kenya. Unpublished master's thesis). University of Nairobi, Kenya.

Coady, D. and Gupta, M.S., 2012. Income inequality and fiscal policy. International Monetary Fund.

Blanchard, O.J., Jaumotte, F. and Loungani, P., 2014. Labor market policies and IMF advice in advanced economies during the Great Recession. IZA Journal of Labor Policy, 3(1), p.2.

Cummings, S.R., Rubin, S.M. and Black, D., 1990. The future of hip fractures in the United States. Numbers, costs, and potential effects of postmenopausal estrogen. Clinical orthopaedics and related research, (252), pp.163166.

Hearn, J.J. and Phaup, M., 2016. Making better budget decisions easier: Some changes suggested by behavioral research.

Hansen, M.C., DeFries, R.S., Townshend, J.R., Carroll, M., DiMiceli, C. and Sohlberg, R.A., 2003. Global percent tree cover at a spatial resolution of 500 meters: First results of the MODIS vegetation continuous fields 
algorithm. Earth Interactions, 7(10), pp.1-15.

Hänninen, V., 2013. Budgeting at a crossroads-The viability of traditional udgeting-A case study.

Faleti, K.O., Faleti, H.O. and Ojeleke, R.O., 2014. Budgetary and management control system for improved efficiency in Public Sector: The implications of "Babariga-Style" Budgeting approach. Scholary Journal of Business Administration, 4(2), pp.44-52.

Jensen, M.C. and Meckling, W.H., 1976. Theory of the firm: Managerial behavior, agency costs and ownership structure. Journal of financial economics, 3(4), pp.305-360.

Le Quéré, C., Andres, R.J., Boden, T., Conway, T., Houghton, R.A., House, J.I., Marland, G., Peters, G.P., Van der Werf, G., Ahlström, A. and Andrew, R.M., 2012. The global carbon budget 1959-2011. Earth System Science Data Discussions, 5(2), pp.1107-1157.

Lienert, M.I. and Sarraf, M.F., 2001. Systemic weaknesses of budget management in Anglophone Africa (No. 1211). International Monetary Fund.

Mugambi, K.W. and Theuri, F.S., 2014. The challenges encountered by county governments in Kenya during budget preparation. IOSR Journal of Business and Management, 16(2), pp.128-134.

Mohammed, B.S., Hossain, K.M.A., Swee, J.T.E., Wong, G. and Abdullahi, M., 2012. Properties of crumb rubber hollow concrete block. Journal of Cleaner Production, 23(1), pp.57-67.

Oates, W.E., 2001. Fiscal competition and European Union: contrasting perspectives. Regional Science and Urban Economics, 31(2-3), pp.133-145.

Niesner, J., Jecha, D. and Stehlík, P., 2013. Biogas upgrading technologies: state of art review in European region. Chem. Eng. Trans, 35, pp.517-522.

Odago, M.O. and Mwajuma, A.A., 2013. Factors affecting effective implementation of eprocurement in county governments: a case study of Kajiado County, Kenya. International Journal of Business \& Law Research, 1(1), pp.94-109.

Olomola, A.S., 2009. Strategies and consequences of budgetary reforms in Nigeria. In Paper for Presentation at the 65th Annual Congress of the Institute of International Public Finance (IIPF), Cape Town, South Africa.

Ongel, V. and Gok, M.S., 2014. The reflections of health spending on the community health: comparative analysis of emerging countries.

Østergren, K. and Stensaker, I., 2011. Management control without budgets: a field study of 'beyond budgeting'in practice. European Accounting Review, 20(1), pp.149-181.

Rashid, N.K.A., Nasir, A., Mustapha, N.H.N. and Kamil, N.F., 2011. Analysis of income and expenditure of households in the east coast of Peninsular Malaysia. Journal of Global Business and Economics, 2(1), pp.5972.

Rodríguez-Pose, A. and Ezcurra, R., 2010. Is fiscal decentralization harmful for economic growth? Evidence from the OECD countries. Journal of Economic Geography, 11(4), pp.619-643.

Wakiriba, J.W., Ngahu, S. and Wagoki, J., 2014. Effects of financial controls on financial management in Kenya's public sector: A case of National Government departments in Mirangine Sub-County, Nyandarua County. Journal of Business and Management, 16(10), pp.105-115. 